Dhaka Univ. J. Biol. Sci. 26(2): 189-198, 2017 (July)

\title{
INCIDENCE OF DISEASES IN GERMPLASMS OF CORCHORUS OLITORIUS L. AND CONTROL OF FUNGAL PATHOGENS
}

\author{
ASM NASIM, S HOSEN AND MA BASHAR* \\ Department of Botany, University of Dhaka, Dhaka-1000, Bangladesh
}

Key words: Incidence, Diseases, Germplasms, Corchorus olitorius, Pathogens

\begin{abstract}
Screening of 40 germplasms and two released varieties of Corchorus olitorius L. was made to determine the source of resistance in jute germplasm against various diseases under condition of natural infection in the field. The germplasm lines were classified on the basis of their per cent disease incidence according to the scale of Mayee and Datar with some modification. There were 12 germplasm lines of Acc. Numbers 1045, 1050, 1060, 1062, 1065, 1143, 1261, 1338, 3711, 3724, 4178,5009 and variety O-72, found resistant to jute diseases which can be utilized for developing disease resistant variety. The effects of Bavistin DF, Capvit $50 \mathrm{WP}$, Dithane M-45, Hayvit 80 WP, Ridomil Gold MZ 68 WG and Tilt 250 EC were evaluated against Botryodiplodia theobromae, Colletotrichum sp., Fusarium sp. 1, Fusarium sp. 2, Rhizoctonia solani and Sclerotium rolfsii at different concentrations following poisoned food technique. Out of six fungicides, Bavistin, Dithane and Tilt completely inhibited the growth of test pathogens except Sclerotium rolfsii at 500 ppm. Bavistin, Dithane and Tilt also showed promising results against the selected test pathogens at 100, 200 and $400 \mathrm{ppm}$. The findings of this investigation will be helpful for the plant breeders to select varieties for breeding purposes as well as to control jute pathogens.
\end{abstract}

\section{Introduction}

Corchorus capsularis L. and C. olitorius L. are commonly known as jute in Bangladesh. Jute (Corchorus spp.) is the second most important fiber after cotton, in terms of usage, global consumption, production and availability. It is a very important cash crop of Bangladesh. Among the jute growing countries of the world, Bangladesh ranks second in respect of production. In 2014-15, 7.5 million bells of jute were produced in the country from 1.66 million acres of land(1). Major constraints of jute production are due to various diseases in which fungal diseases are most important one. It has been estimated that about $60 \%$ yield of jute fiber are lost due to the incidence of fungal diseases alone every year. Major diseases of jute plants in Bangladesh are stem rot (Macrophomina phaseolina), anthracnose (Colletotrichum corchori and C. gloeosporioides), soft rot (Sclerotium rolfsii), black band (Botryodiplodia theobromae), die-back (Gloeosporium sp.), root rot (Rhizoctonia sp.) and powdery mildew (Oidium sp.). They are not only responsible for yield loss but also deteriorate the quality of fiber and seeds ${ }^{(2)}$.

*Author for correspondence: <botanybashar@yahoo.com>. 
Germplasm is the major source of genetic resources of any crop. At present there are 6060 germplasms including 4084 of Corchorus (15 species), 1512 of Hibiscus (22 species), 345 of allied genera (15 species) and 119 of interspecific hybrid preserved in Genetic Resources and Seed Division of Bangladesh Jute Research Institute. Plant breeders are always searching disease resistant traits by screening germplasm time to time as their routine work. Very few reports are available on the screening of germplasm against various diseases of jute. So, it is very important to screen plant genetic resources of jute, so that disease resistant germplasm line can be recommended for further crop improvement program or directly released as disease resistant variety.

Nowadays, many inorganic and organic fungicides are used to control plant diseases $^{(3)}$. Various workers in different countries of the world evaluated the efficacy of various fungicides against Colletotrichum spp., Macrophomina phaseolina, Fusarium spp., Botryodiplodia theobromae, Colletotrichum gloeosporioides, Sclerotium rolfsii and Alternaria spp., under laboratory and field conditions ${ }^{(4,5,6)}$. Very few works have been done for the control of fungal pathogens associated with various diseases of $C$. olitorius by fungicides. Hence, the present work was undertaken to find out disease resistant germplasm by screening plant genetic resources and in vitro fungitoxicity of fungicides of fungal pathogens of $C$. olitorius.

\section{Material and Methods}

Seeds of 40 different germplasm lines and two released varieties of Corchorus olitorius were collected from Genetic Resources and Seed Division of Bangladesh Jute Research Institute (BJRI), Manik Mia Avenue, Dhaka. Experiment was conducted at BJRI Agricultural Experimental Station, Manikganj and Mycology and Plant Pathology Laboratory, Department of Botany, University of Dhaka during April, 2013 to June, 2014. Jute seeds were sown in the 2nd April, 2013 in line at $3 \mathrm{~cm}$ depth, maintaining $20 \mathrm{~cm}$ seed to seed and $30 \mathrm{~cm}$ line to line distances. The block to block distances were $1 \mathrm{~m}$ from each other. Per cent disease incidence of plant in each individual line was calculated by using following formula:

$\%$ disease incidence $=\frac{\text { Number of infected plants }}{\text { Total number of plants }} \times 100$

After counting the per cent disease incidence of plants were categorized as immune, resistant, moderately resistant, moderately susceptible, susceptible and highly susceptible according to the scale given by Mayee and Datar(7) with some modifications (Table 1).

Disease samples were collected in separate sterile polyethylene bags, labeled properly and then brought to the laboratory for isolation of fungi following "Tissue 
planting method" on PDA medium ${ }^{(8)}$. Identification of the isolates was determined following standard literatures ${ }^{(9-13)}$.

Six fungicides viz., Bavistin DF (50\% Carbendazim), Capvit 50 WP (Cupper oxychloride), Dithane M-45 (80\% Mancozeb), Hayvit 80 WP, Ridomil Gold MZ 68 WG (4\% Metalaxyl and 64\% Mancozeb) and Tilt 250 EC (Propiconazole) were selected to evaluate their in vitro efficacy against the test pathogens following poisoned food technique(14). Firstly, in vitro fungitoxicity of these six fungicides at $500 \mathrm{ppm}$ was evaluated against the six test pathogens to screen out the effective fungicides. The fungicides which were effective at 500 ppm were further tested in 100, 200 and 400 ppm to find out their minimal inhibitory concentration.

Table 1. Categorization of plants on the basis of percentage of disease incidence (After Mayee and Datar with some modification).

\begin{tabular}{cll}
\hline Scale & Per cent disease incidence & Categories \\
\hline 0 & No symptom of disease & Immune/highly resistant \\
1 & $1-10 \%$ plants affected & Resistant \\
3 & $11-20 \%$ plants affected & Moderately resistant \\
5 & $21-50 \%$ plants affected & Moderately susceptible \\
7 & $51-70 \%$ plants affected & Susceptible \\
9 & $71 \%$ and above & Highly susceptible \\
\hline
\end{tabular}

For each fungicide, a stock solution having the concentration of $10000 \mathrm{ppm}$ was prepared. The calculated amount of stock solution of fungicide as supplemented with sterilized PDA medium to get the concentrations of 100, 200, 400 and 500 ppm, respectively. In control set, required amount of water was used instead of a fungicide. Then $15 \mathrm{ml}$ of medium was poured in each Petri plate and allowed them to solidify. Then test pathogen was inoculated at the center of the plate with a $5 \mathrm{~mm}$ mycelial agar disk cut from the margin of actively growing culture of it. Three replications were maintained in each case. The inoculated plates were incubated at $25 \pm 2^{\circ} \mathrm{C}$. The radial growth of the colonies was measured after 7 days of incubation. The per cent growth inhibition of each test fungus was calculated by using the formula used by Hossain and Bashar ${ }^{(5)}$.

\section{Results and Discussion}

Total number of plants, diseased plants and percentage of disease incidence in 40 germplasm lines and 2 released varieties of Corchorus olitorius are presented in Table 2. In case of 40 germplasm lines and two released varieties, six fungal diseases (stem rot, die back, soft rot, root rot, black band and anthracnose), two viral diseases (leaf mosaic and leaf curl) and one nematode (root knot) disease were recorded. 


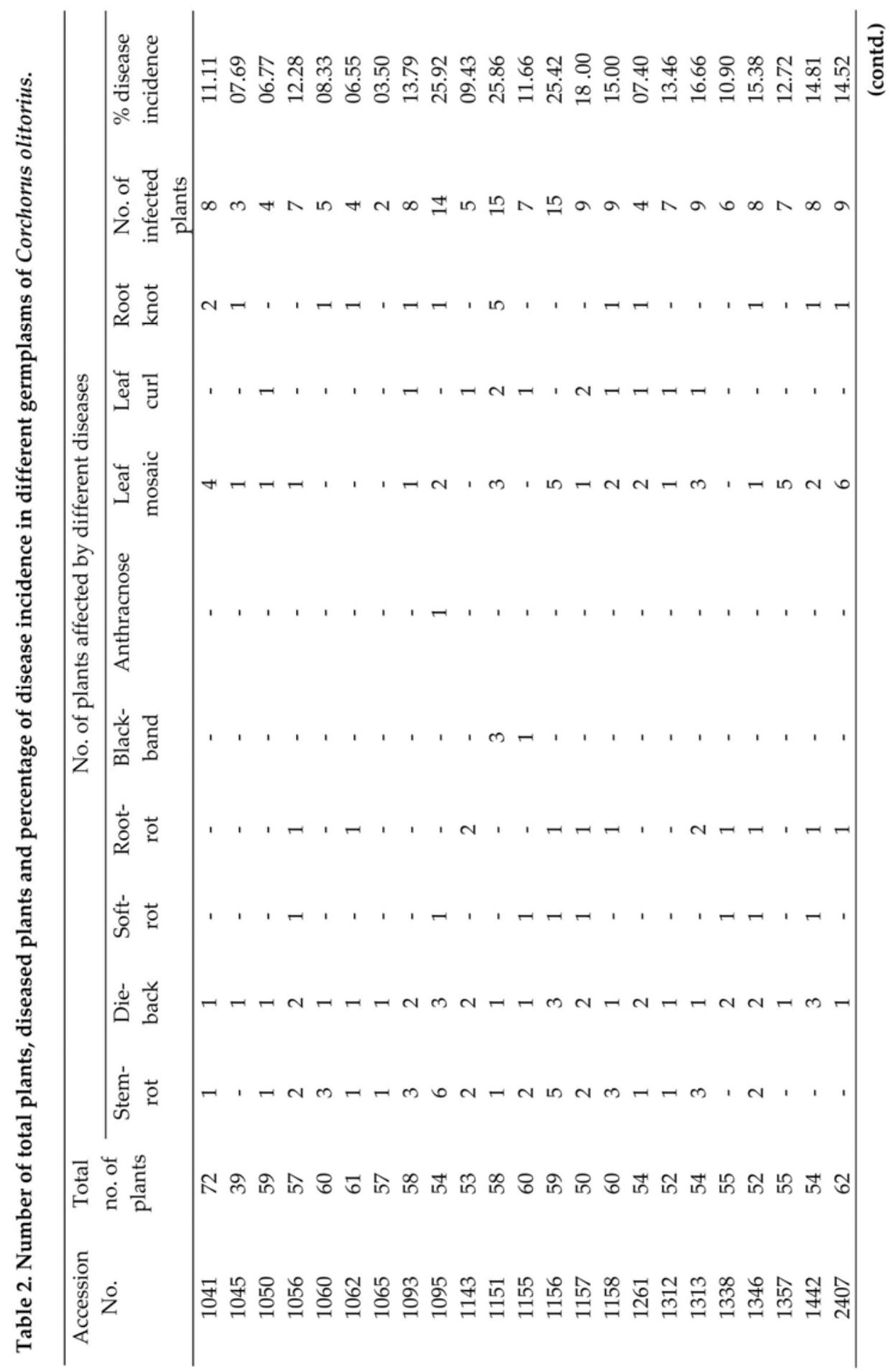




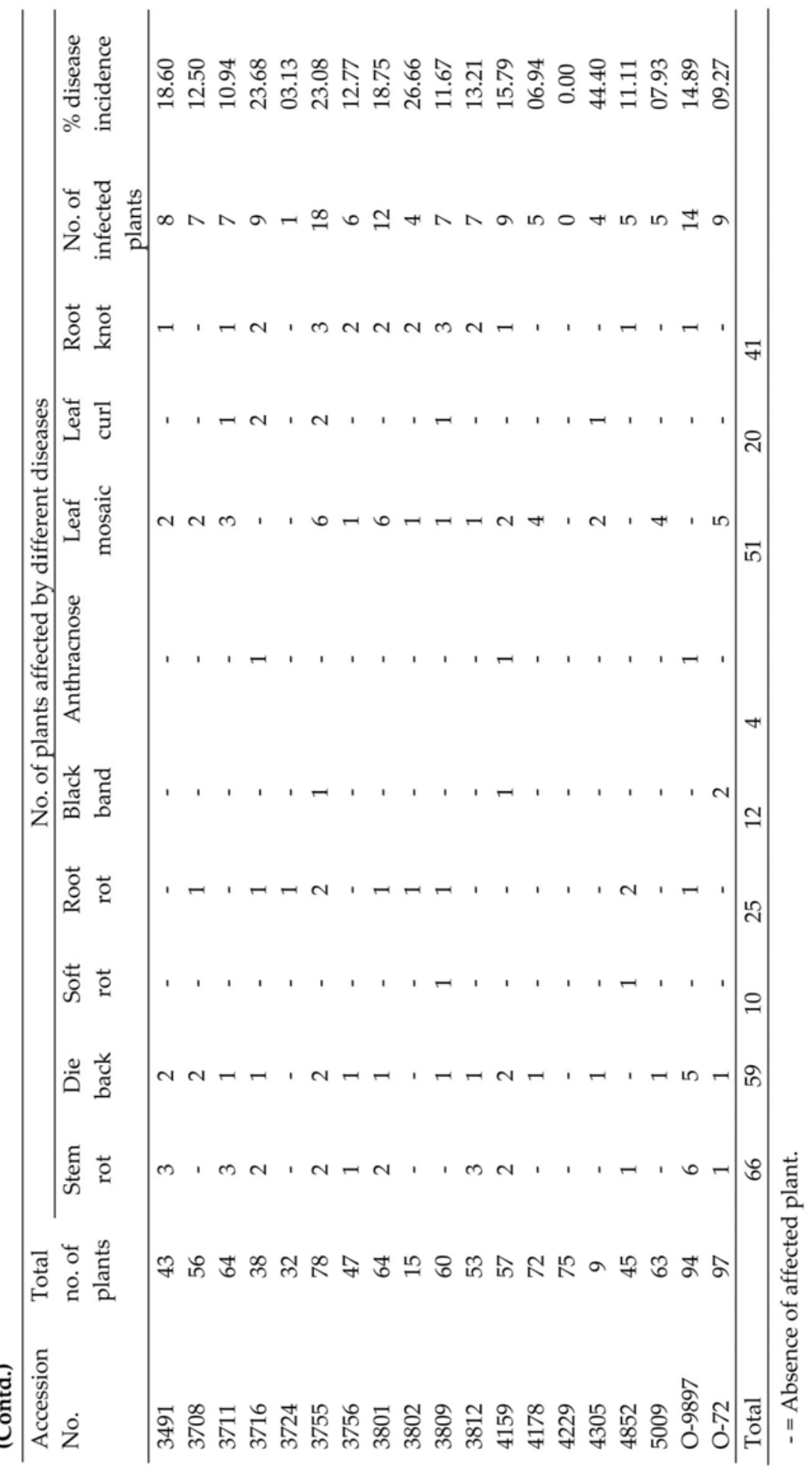


Maximum number of jute plants was infected by stem rot (66) disease as followed by die back (59), leaf mosaic (51), root knot (41), root rot (25), leaf curl (20), black band (12), soft rot (10) and anthracnose (4) (Table 2).

In case of individual disease evaluation highest number of stem rot was observed in Acc. number 1095 and variety O-9897. There was no stem rot in Acc. numbers 1045. 1338, $1357,1442,2407,3708,3724,3802,3809,4178,4229,4305$ and 5009. The highest number of die back was observed in variety O-9897 and it was absent in Acc. numbers 3724, 3802, 4229, 4305 and 4852. The highest number of root rot was observed in Acc. numbers 1143 ,1313, 3755, 4852, and was absent in Acc. numbers 1041, 1050, 1060, 1065, 1093, 1095, 1151, $1155,1261,1312,1357,3491,3711,3756,3812,4159,4178,4229,5009$ and variety O-72 (Table 2). Less number of soft rot was observed in Acc. numbers 1056 1095, 1155, 1156, 1157, 1338, 1346, 1442, 3809 and 4852. Accession numbers 1151, 1155, 3755, 4159 and variety O-72 showed less number of black band disease. Anthracnose was rarely observed in Acc. numbers 1095, 3716, 4159 and variety O-9897. Leaf mosaic was observed in young stage in highest number in Acc. number 3755 and absent in Acc. numbers 1060, $1062,1065,1143,1155,1338,3716,3724,3809,4229,4852$ and variety O-9897. Accession numbers 1050, 1093, 1143, 1151, 1155, 1157, 1158, 1312, 1313, 37113716, 3755, 3756, 3809 and 4305 showed less number of leaf curl disease. Highest number of root knot was observed in Acc. number 1151 and it was absent in Acc. numbers 1050 , 1056, 1065, 1143, $1155,1156,1157,1261,1313,1338,3708,3724,4178,4229,4305,5009$ and variety O-9897 (Table 2).

According to the scale of Mayee and Datar(7) with some modification only Accession number 4229 behaved as highly resistant or immune. Twelve germplasm lines viz., Accession numbers 1045, 1050, 1060, 1062, 1065, 1143, 1261, 1338, 3711, 3724, 4178, 5009 and released variety O-72 were found resistant. Twenty germplasm lines viz., Accession numbers 1041, 1056, 1093, 1155, 1157, 1158, 1312, 1313, 1346, 1357, 1442, 2407, 3491, 3708, $3756,3801,3809,3812,4159,4852$ and released variety O-9897 were moderately resistant. Seven germplasm lines of Acc. numbers 1095, 1151, 1156, 3716, 3755, 3802 and 4305 responded as moderately susceptible. None of the varieties and germplasm line behaved as susceptible and highly susceptible according to Mayee and Datar(7).

A total of six pathogens viz., Botryodiplodia theobromae, Colletotrichum sp., Fusarium sp.1, Fusarium sp. 2, Rhizoctonia solani and Sclerotium rolfsii were selected as test pathogens owing to their previous report as jute pathogens(15-17) (Fig. 1).

Results of six fungicides on the radial growth of test pathogens at $500 \mathrm{ppm}$ are presented in Table 3. Out of six fungicides Bavistin, Dithane and Tilt showed the complete growth inhibition of the test pathogens except Sclerotium rolfsii in case of Bavistin. These three fungicides were again tested in 100, 200 and 400 ppm concentrations to find out their minimal requirement of concentration. 

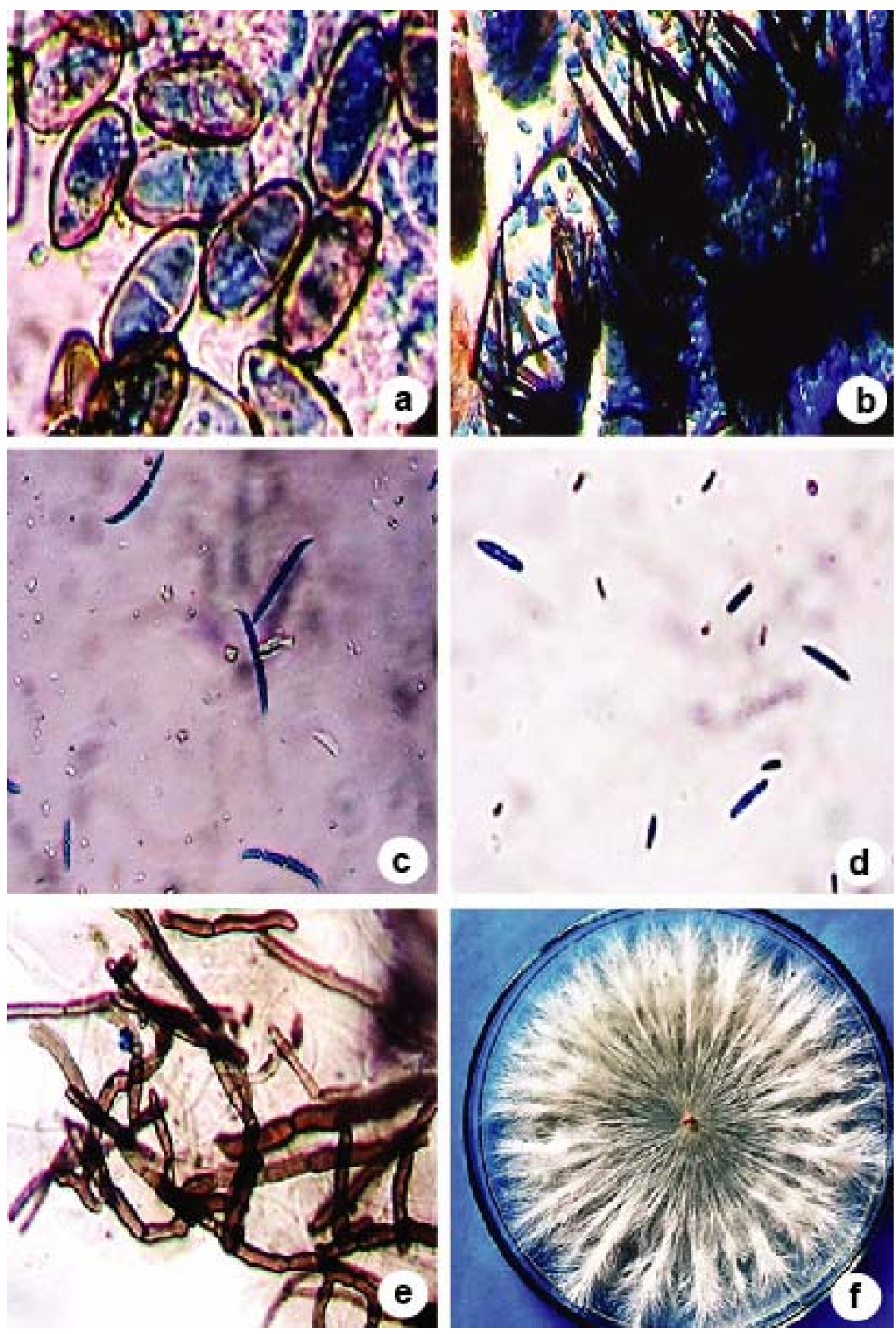

Fig. 1. Different pathogens of Corchorus olitorius. a. Conidia of Botryodiplodia theobromae, b. Conidia and setae of Colletotrichumsp., c-d. Macro and micro conidia of Fusarium sp. 1 and Fusarium sp. 2, e. Mycelium of Rhizoctonia solani and f. Mycelium of Sclerotium rolfsii. 
Effects of Bavistin, Dithane and Tilt on the radial growth of the test pathogens at 100, 200 and 400 ppm are presented in Table 4. Bavistin showed complete growth inhibition of all the test pathogens at $400 \mathrm{ppm}$ except S. rolfsii. Bavistin also showed complete growth inhibition of all the test pathogen sat 100 and 200 ppm except Colletotrichum sp. and S. rolfsii. Bashar ${ }^{(18)}$ reported that bavistin checked the complete growth of $F$. oxysporum f. sp. ciceri, causal agent of chickpea wilt at $100 \mathrm{ppm}$. Chakraborty et al.(19) reported that, at $0.5 \%$ dose, bavistin happened to be the most efficient one contributing the highest inhibition (83.7\%) of growth of Fusarium solani causing wilt of brinjal under in vitro condition.

Table 3. Fungitoxicity of fungicides against the test pathogens at $500 \mathrm{ppm}$ concentration.

\begin{tabular}{lcccccc}
\hline Fungicides & \multicolumn{5}{c}{ \% inhibition of radial growth of test pathogens } \\
\cline { 2 - 7 } & $\begin{array}{c}\text { Botryodiplodia } \\
\text { theobromae }\end{array}$ & $\begin{array}{c}\text { Colletotrichum } \\
\text { sp. }\end{array}$ & $\begin{array}{c}\text { Fusarium } \\
\text { sp.1 }\end{array}$ & $\begin{array}{c}\text { Fusarium } \\
\text { sp.2 }\end{array}$ & $\begin{array}{c}\text { Rhizoctonia } \\
\text { solani }\end{array}$ & $\begin{array}{c}\text { Sclerotium } \\
\text { rolfsii }\end{array}$ \\
\hline Bavistin DF & 100 & 100 & 100 & 100 & 100 & 100 \\
Capvit 50 WP & 100 & 100 & 100 & 100 & 100 & 100 \\
Dithane M 45 & 100 & 100 & 100 & 100 & 100 & 5.36 \\
Hayvit 80 WP & 100 & 66.66 & 56.09 & 45.83 & 100 & 100 \\
Ridomil Gold & 62.22 & 25.00 & 46.67 & 37.06 & 100 & 4.34 \\
MZ 68 WG & & & & & & \\
Tilt 250 EC & 73.88 & 56.41 & 46.34 & 25.00 & 26.11 & 33.33 \\
\hline
\end{tabular}

The complete growth inhibition of R. solani, S. rolfsii and Fusarium sp.1 was observed at 400 ppm except B. theobromae (88.90\%), Colletotrichum sp. (83.63\%) and Fusarium sp.2 (64.06\%). The highest growth inhibition of Fusarium sp.1 (100\%) was noticed at $100 \mathrm{ppm}$ which was followed by B. theobromae $(78.90 \%)$, S. rolfsii $(77.78 \%)$, Colletotrichum sp. $(70.90 \%)$, R. solani $(66.67 \%)$ and Fusarium sp. 2 (50\%). The highest growth inhibition of Fusarium sp.1 (100\%) was found at $200 \mathrm{ppm}$ concentration which was followed by $S$. rolfsii $(91.11 \%)$, B. theobromae $(82.22 \%)$, R. solani $(80 \%)$, Colletotrichum sp. $(78.18 \%)$, and Fusarium sp. 2 (56.25\%) (Table 4). Javaid et al.(20) reported that out of four fungicides such as Acrobat MZ, Dithane M-45, Aliette and Ridomil Gold, Dithane was found to be the most effective against Colletotrichum gloeosporioides. There were $60-66 \%$ reduction in fungal biomass owing to application of recommended and various lower doses of this fungicide. Dithane was also effective in controlling yam (Discorea rotundata) rot fungi, namely Aspergillus, Botryodiplodia, Fusarium, Penicillium and Rhizopus ${ }^{(21)}$.

The maximum growth inhibition at $100 \mathrm{ppm}$ was observed in $R$. solani (90\%) followed by Fusarium sp. 1 (86.27\%), S. rolfsii (85.56\%), Colletotrichum sp. (82.14\%), B. theobromae (69.44\%) and Fusarium sp. 2 (61.29\%). The complete growth inhibition of Colletotrichum sp., Fusarium sp. 1 and R. solani was observed at 200 and 400 ppm (Table 4). The same fungicides also showed different effects on different pathogens in the present 
investigation due to the selection of different test pathogens. In contrast to the present study, Singh et al.(22) reported that Tilt 25 EC was found most effective to inhibit Colletotrichum gloeosporioide $100 \mathrm{ppm}$ followed by hexaconazole and carbendazim. Handiso and Alemu ${ }^{(23)}$ reported that Tilt 250 EC showed 99.33, 99.33 and 68.33\% growth inhibition of Colletotrichum capsici at 150, 250 and 300 ppm, respectively.

Table 4. Per cent inhibition of radial growth of test pathogens with different fungicides at various concentrations.

\begin{tabular}{lccccccc}
\hline Fungicides & $\begin{array}{c}\text { Conc. } \\
\text { (ppm) }\end{array}$ & \multicolumn{5}{c}{ \% inhibition of radial growth of test pathogens } \\
\cline { 3 - 7 } & & $\begin{array}{c}\text { Botryodiplodia } \\
\text { theobromae }\end{array}$ & $\begin{array}{c}\text { Colletotri- } \\
\text { chum sp. }\end{array}$ & $\begin{array}{c}\text { Fusarium } \\
\text { sp. } 1\end{array}$ & $\begin{array}{c}\text { Fusarium } \\
\text { sp. } 2\end{array}$ & $\begin{array}{c}\text { Rhizoctonia } \\
\text { solani }\end{array}$ & $\begin{array}{c}\text { Sclerotium } \\
\text { rolfsii }\end{array}$ \\
\hline Bavistin DF & 100 & 100 & 89.09 & 100 & 100 & 100 & 0.00 \\
& 200 & 100 & 89.09 & 100 & 100 & 100 & 0.00 \\
& 400 & 100 & 100 & 100 & 100 & 100 & 0.00 \\
Dithane & 100 & 78.9 & 70.90 & 100 & 50.00 & 66.67 & 77.78 \\
M 45 & 200 & 82.22 & 78.18 & 100 & 56.25 & 80.00 & 91.11 \\
& 400 & 88.90 & 83.63 & 100 & 64.06 & 100 & 100 \\
Tilt 250 EC & 100 & 69.44 & 82.14 & 86.27 & 61.29 & 90 & 85.56 \\
& 200 & 88.89 & 100 & 100 & 70.96 & 100 & 91.11 \\
& 400 & 94.44 & 100 & 100 & 74.20 & 100 & 100 \\
\hline
\end{tabular}

In the present study, 12 germplasm lines of Acc. numbers 1045, 1050, 1060, 1062, $1065,1143,1261,1338,3711,3724,4178,5009$ and one released variety O-72 found to be resistant to jute diseases which can be utilized for developing disease resistant variety. Efficiency gradients observed in the present investigation expressed that Bavistin DF, Dithane M-45, and Tilt 250 EC were the best inhibiting agent against the in vitro growth of the test pathogens associated with Corchorus olitorius.

\section{References}

1. Anonymous 2015. Statistical Yearbook of Bangladesh. 27th Series, Statistics and Informatics Division, Ministry of Planning, Govt. of the People's Republic of Bangladesh, Dhaka. pp. 557.

2. Biswas AC, MA Taher, M Asaduzzaman, K Sultana and AKM Eshaque 1980. Loss of yield and quality of fiber due to prevalence of stem rot. Bangladesh J. Plant Pathol. 1: 61-62.

3. Mehrotra RS 2000. Plant Pathology. Tata McGraw Hill Publishing Co., New Delhi. pp. X+771.

4. Sharma A and KS Verma 2007. In vitro cross pathogenicity and management of Colletotrichum gloeosporioides causing anthracnose of mango. Ann. Plant Protec. Sci. 15(1): 186-188.

5. Hossain KS and MA Bashar 2011. In vitro effect of plant extracts, fungicides and antibiotics on the fungal isolates associated with damping-off disease of crucifers. J. Agrofor. Environ. 5(2): 17-20.

6. Ahmed MJ, KS Hossain and MA Bashar 2014. Anthracnose of betel vine and its in vitro management. Dhaka Univ. J. Biol. Sci. 23(2): 127-133. 
7. Mayee CD and VV Datar 1986. Phytopathometry, Technical Bulletin No. 1. Marathwada Agriculture University, Parbhani, India.

8. Anonymous 1968. Plant Pathologist's Pocket Book. $1^{\text {st }}$ edn. The Commonwealth Mycological Institute, England. pp. 267.

9. Booth C 1971. The Genus Fusarium. The Commonwealth Mycological Institute, Kew, Surrey, England. pp. 237.

10. Barnett HL and BB Hunter 1972. Illustrated Genera of Imperfect Fungi. Burgess Pub. Co. USA.pp. III +241.

11. Ellis MB 1971. Dematiaceous Hyphomycetes. The Commonwealth Mycological Institute, England. pp. 608.

12. Ellis MB 1976. More Dematiaceous Hyphomycetes. The Commonwealth Mycological Institute, England. pp. 608.

13. Sutton BC 1980. The Coelomycetes. Fungi Imperfecti with Pycnidia, Acervuli and Stromata. Commonwealth Mycological Institute, England. pp . 696.

14. Pennycook SR and JB Corbin 1970. A preliminary laboratory assessment of fungicides for the control of Sclerotinia sclerotiorum (LIB) DBY. Tone 16: 21-30.

15. Wadud MA and Ahmed QA 1962. Studies on fungus organisms associated with wilted jute plants. Mycopathologiaet Mycologia Applicata 18(1\&2): 107-114.

16. Niu X, H Gao, J Qi, M Chen, A Tao, J Xu, Z Dai and J Su 2016. Colletotrichum species associated with jute (Corchorus capsularis L.) anthracnose in southeastern China. Sci. Rep. 6: 25179.

17. Biswas C, P Dey, S Satpathy, SK Sarkar, A Bera and BS Mahapatra 2013. A simple method of DNA isolation from jute (Corchorus olitorius) seed suitable for PCR based detection of the pathogen Macrophomina phaseolina (Tassi) Goid. Letters in Applied Microbiology 56: 105110.

18. Bashar MA 1992. Laboratory evaluation of some pesticides against Fusarium oxysporum f. sp. ciceri causing wilt of chickpea. Bangladesh J. Bot. 21(1): 157-159.

19. Chakraborty MR, NC Chatterjee and TH Quimio 2009. Integrated management of fusarial wilt of eggplant (Solanum melongena) with soil solarization. Micologia Aplicada International. 21(1): 25-36.

20. Javaid A, N Akhtar, M Akbar and N Zaman 2007. In vitro chemical control of Colletotrichum gleosporioides. Int. J. Biol. Biotech. 4(1): 79-81.

21. Efiuvwevwere BJO and E Nwachukwu 1998. Incidence of yam (Discorea rotundata Poir) rots, inoculation induced quality changes, and control by chemical fungicides and modified atmospheres. Posthar. Biol. Tech. 14: 235-243.

22. Singh S, KKK Chinnaswamy, D Subramani, SS Bhat and Jayarama 2012. In vitro evaluation of fungicides against Colletotrichum gloeosporioides, the causal agent of anthracnose disease of coffee. Acta Biologica Indica 1(2): 249-251.

23. Handiso $\mathrm{S}$ and $\mathrm{T}$ Alemu 2017. In vitro evaluation of fumgicides, plant extracts and antagonists (Trichoderma spp.) on chili anthracnose Colletotrichum capsici (Syd.). I. J. S. B. A. R. 34(1): 226-236. 